\title{
Archive as a Depository of Shared Memories, History and Identity
}

DOI: https://doi.org/10.11567/met.36.2.3 UDK: $930.25: 323.1$ $930.25(497.5)$

930.25(497.1)

Izvorni znanstveni rad Primljeno: 29.10.2020. Prihvaćeno: 24.2.2021.

\author{
Viktorija Kudra Beroš \\ Institute for Migration and Ethnic Studies, Zagreb \\ viktorija.kudra@imin.hr
}

\section{SUMMARY}

Given their role in the preservation and protection of an authentic and credible trace of the past (documents) and, consequently, national identity, archives are considered places of choice for interpreting and representing shared memory and the past. Emphasising authenticity and credibility frames archives as seemingly neutral institutions in terms of politics and ideology. However, the trace that provides an insight into the "truth and knowledge" of our (individual and collective) past "that makes us what we are" needs to be questioned. Since the archiving procedure is based on the processes of inclusion and exclusion in all segments of everyday interpretation of material, the archive is a political and ideological institution that takes its place in the order of political power. This paper discusses the role of the archive as a place of preservation of "shared past and history" as an important part of national identity through the prism of institutional apparatuses or forms of knowledge/power (example of architecture) and technologies or manners of articulating and practising knowledge/power (example of everyday practice). The paper points to the role of archives in the (re)interpretation and (re)vision of shared memories, collective history and national identity on the examples of the Croatian State Archives and Archives of Yugoslavia, in the context of changes in the symbolic and political order (SFRY/Croatia). By constructing national memory and narratives of nationality through narratives of history and memory, and by constructing "truth" (knowledge) through exclusion and inclusion, archives (just like museums and libraries) have a role to play in "imagining" the community-nation. Or, according to the theory of performative identity (Foritier 2000), everyday practice that takes place in archives is an institutional identity practice that contributes to the unification and homogenisation of the community through a policy of interpretation by performing and producing (performative) memory (collective identity formation).

KEY WORDS: archive, memory, national identity, Croatian State Archives, Archives of Yugoslavia 


\section{INTRODUCTION}

In the context of migration, Anne-Marie Fortier (2000: 157) labels memory as the primary area of identity construction. Following Fortier, one can say that, even in the context of a homeland, the construction of a national identity or national affiliation rests on "shared memory" in the sense of belonging to a shared history. According to Nora (2006: 30), modern society establishes archives not only because of the technological possibilities of creating and preserving documents "but also as a result of superstition and the worship of traces." There is a need to re-examine the creation of archives to fulfil the need to "worship the traces" that constitute and give us insight into the "truth and knowledge" about our own (individual and collective) past "that makes us what we are." On the one hand, this re-examination should look at the notion of archive in general (what constitutes an archive), and on the other, the archive as an institution, its role, and practices that occur there, as well as their effects.

The "professional" definition of archives ${ }^{1}$ explicitly underlines the physical and the historical aspects (place/space, material), while the aspect of institutional authority (representation and interpretation), which attaches value to both the material and the place (institutionalisation of the private into the public through processes of inclusion and inclusion) $)^{2}$ is merely implied.

1 Archival science as a profession defines the term "archive" in four ways. First, as an institution that results from the activities of state institutions and individuals who have played a prominent role in history, and is tasked with the collection, storage, research and provision of documents and material while emphasising its lasting value. Second, as a physical place, i.e., a building or a room intended for storing "valuable" material. Third, as a part of an institution's registry. Fourth, as the material itself, that is collected and stored and thereby attached value (Kolbas, 2006).

2 Derrida (1995), on the other hand, approaches the concept of archives by analysing the etymology of the word archive. Derrida (1995: 1) points out that the Greek word arkhé, naming at once the commencement and the commandment, is associated with two principles; on the one hand, a physical, historical or ontological principle of the beginning of things according to nature or history; on the other, a nomological principle related to authority and order as a divine or human law (and law as a document). The concept of archives covers both of them. The Greek word arkheion denoted a building, a home, a place where the archons (the chosen ones) lived and worked. They had the authority to represent and interpret laws and official documents entrusted to them for storage, which they collected and classified (Derrida, 1995: 2). Thus, arkheion is a dual space. It is both public and private. As noted by Derrida (1995: 2), the duality of arkheion, and thus of the archives, marks the "institutional passage from the private to the public" (as well as the merging of space and law), which opens a path towards the secret (hidden) and the nonsecret (public) or, as Voss and Werner (1999: i) point out, it is a meeting point between the public (historical) and private (hermetic) spaces. Preservation in a public/outdoor place is precisely what constitutes the archive while at the same time it "assures the possibility of memorization, of repetition, of reproduction, or of reimpression" (Derrida, 1995: 11). 
Contemporary discussions on the role of archives and archival discourse address this very aspect of institutional authority, questioning not only the role of the archive (the institution) but also the archiving process based on processes of inclusion and exclusion in all segments of everyday practice and interpretation or representation of materials (Manoff, 2004: 14). For Derrida (1995: 7), the archival function of institutionalisation (external/ public place) constitutes a dimension of the revolutionary, while the one of preservation falls under the domain of the traditional. Referring to psychoanalysis, Derrida (1995: 7) points out that the combination of the two, as the basis of archives, is unnatural, embodying violence (archival violence) since it merges opposing principles - preservation (archival drive) and destruction (death drive). Through archiving processes and the structure of archives, these opposing principles become a foundation for constructing history, memory, and tradition, bridging the past, the present, and the future, because, according to Derrida (1995: 36), the issue of archives is an issue of the future.

Gillian Rose (2016: 221) argues that one should pay special attention to the effects of archives both on those who use them (subject positions) and on objects that are stored and preserved. Following Rose (2016: 223; see also Hall, 1997), who draws inspiration from Foucault (1994), this paper approaches the archive as an institution from two angles. The first one sees the archive as a space of "forms of knowledge/power" (institutional apparatuses) that are constituents of institutionalisation (Rose, 2016: 223) and occupying the position of institutional authority (examples are architecture, legal and other regulations, such as scholarly disciplines). The second refers to institutional technologies, which Rose (2016: 223) 3 perceives as ways of articulation and practice of knowledge/power.

In that context, this paper analyses the institutional role of archives as depositories of the "shared past and history" as important constituents of national identity, and then also, through the lens of institutional apparatuses and technologies, as significant spaces within the order of political power for the (re)interpretation and (re)vision of shared memories, collective history and national identity on the examples of the Croatian State Archives and Archives of Yugoslavia, in the context of changes in the symbolic and political order (SFRY/Croatia).

3 Rose (2016: 223) points out that Foucault's distinction between institutional technologies and the apparatuses through which institutions operate is not very clear, although he listed them as two forms of operation. 


\section{INSTITUTIONAL AUTHORITY OF THE ARCHIVE}

As a place of choice for interpreting and representing shared memory and the past, the archive takes the position of institutional authority through everyday practices that include collection and classification (introducing order), preservation and protection, which constitute the archiving process, as well as other daily procedures (circulation of material, i.e., specifying who may view/use the material and in what way, providing information services). All these procedures establish the archive as a place of total knowledge (history), allowing it to appropriate the truth, i.e., to assume the position of a producer of knowledge and truth about shared history and past. They also validate its significance in the public and political space, or the space of political power, and the structuring of reality. The self-representational narrative of the Croatian State Archives shows how the position in the order of political power is seemingly neutralised by referring to the preservation and protection of the authentic and credible (documented) trace of the past, to which everyday archival practices are devoted, at the same time assuming institutional authority.

"Archives, institutions specialising in the preservation, protection, processing, and use of original written heritage, preserve an authentic and credible trace of the past as well as the events documented in these records while protecting and advocating the interests and rights of citizens. In doing so, they also preserve testimonies of historical events, everyday life and artistic creation, as well as the identity and fundamental values of the environment to which they belong" (Croatian State Archives official internet page). ${ }^{4}$

White (1987: 59) argues that "interpretation presupposes politics as one of the conditions of its possibility as a social activity." The politics of interpretation, as White points out (1987: 60), is aimed at questioning how knowledge, especially historical, is instrumentalised for political purposes and put into a particular function. An interest in the politics of interpretation emerges in contemporary historical studies. The politics of interpretation is clearly visible when it is motivated by political values or an ideology (interpretation of politics), i.e., politics. However, when linked to practices that are not explicitly political, that is, when implemented as "a purely disinterested search for the truth or inquiry into the natures of things" (especially concerning history), its visibility is lost and blurred (White, 1987: 58). The

4 Archival Service Croatian State Archives, http://www.arhiv.hr/Arhivska-sluzba (accessed on 27 September 2019). 
invisibility of the politics of interpretation, which invokes truth and knowledge, creates and reinforces the position of institutional authority, allowing the archive to assume its place in the order of political power. As pointed out by Derrida (1995: 4), "there is no political power without control of the archive", which includes control of memory using the politics of interpretation. The possession and mediation of knowledge, i.e., management of knowledge/memory within the order of political power points to the space of ideology. Having in mind the archiving process, which is a medium for opposing principles (memory preservation and destruction - loss/exclusion), and the archival structure, which jointly depend on technologies and techniques (Derrida, 1995: 17), the question arises as to the actual content of the archive and the role of institutional authority in it.

According to archival science, the archive's role is to collect and store materials resulting from the activities of state institutions or individuals ${ }^{5}$ who played a significant role in history and label them as valuable. The definition of the archive reveals selectivity/partiality and an opportunity to exclude a large amount of material by not labelling it as valuable. The position of institutional authority legitimises the process of attaching value, i.e., the processes of inclusion and exclusion through attaching value. Derrida (1995: 100) points out that the archive only contains traces, which makes it incomplete (1995: 52) and open (1995: 68). The archive's ambivalence, visible in the heterogeneity and fragmentation of both the content/objects and context collected and stored (Voss and Werner, 1999: ii) and those lost or excluded, prevents complete decoding of history (memory and tradition). This impossibility of complete decoding and the process of construction through heterogeneous fragments (memory, history and tradition) places the archive, as already mentioned, within the space of ideology. It also creates an opportunity to critically challenge the role of archives in that same space and highlight the need for awareness that archives do not contain objects and documents that present (record) a neutral image of history (truth, knowledge) in its entirety. Instead, they provide a certain construction and

5 Kecskeméti (1999) distinguishes two models of the archival service with regard to the role and competence of the national (state) archival service and the exclusion from that system. The first model, which he calls the "French model", is widespread in European countries and takes its most extreme form in the Soviet Union (Eastern Bloc). On the one hand, it is marked by large central (state) competence, and on the other, exclusion of archival materials of political or state security (repressive) institutions (foreign and internal affairs, defence, security services), which themselves establish the criteria for archival processes and the use of material. The second model is called the "English model". It is characterised by less central competence (institutions may store their material themselves), but state institutions are not excluded from the system. 
interpretation of history, tradition, and memory through selected objects and documents (Manoff, 2004; Derrida, 1995; Rose, 2016; Brown and Davis-Brown, 1998). Therefore, the discussion should concern not only what the archives contain but also what they exclude (Manoff, 2004: 14-15). As a place that contains selected and fragmented objects and documents and participates in the discourse-generated construction and interpretation of history, memory and tradition (i.e., knowledge, truth), the archive appears to be a political and ideological institution that uses processes of inclusion and exclusion from a position of institutional authority to construct collective (national) memory, tradition and knowledge. This further underlines the need to subject it to a critical challenge. ${ }^{6}$

Institutional significance and attachment to collective memory are reflected in the temporal dimension of connecting the past, the present and the future. Derrida (1995: 33) argues that archives reveal their meaning in the future, that is when the future becomes the present. However, that future is not predictable - one cannot guess what will affect it (Derrida, 1995: 70). However, (re)constructing the past/history or "moving down (or along) history", as Anderson (1990: 33) points out, opens up spaces for various interpretations and (re)interpretations of "common history" based on heterogeneous fragments, which is reflected in the future.

\section{THE POLITICS OF ARCHIVES AS A POLITICS OF MEMORY AND IDENTITY}

Starting from the definition of an archive as a repository, or a place and space in which materials of historical interest or social significance are stored and ordered, Brown and Davis-Brown (1998: 17) associate the concept of archives with collective (national) memory. They point out that, through their everyday work, archivists (as well as museologists and librarians) perform and produce the politics of archives as a politics of memory, appropriating

$6 \quad$ The position and role of archives may be understood from the position of archival science within the scientific system. Like library science and museology, archival science falls under the information and communication sciences within social sciences. This points to the institutional possession of knowledge as well as its institutional mediation (management of knowledge - space of ideology), thus constructing the subject position of the expert (Rose, 2016: 231), which implies institutional authority. The linking of institutional techniques or everyday practices with the institutional discursive system of science as positions of power that produce expert authority further consolidates and reinforces the institutional role of archives in forming knowledge and collective memory, i.e., fortifies the position of archives within the order political power. 
truth and knowledge and trying to consolidate the constitutive norms of the collective past involved in the construction of collective identity (Brown and Davis-Brown, 1998). The politics of memory thus becomes an important part of the politics of identity. Brown and Davis-Brown (1998: 18-19) link the increasing institutional significance of archives, museums and libraries to the modern period and the development of late-capitalist society. They underline their role as institutions that "help preserve the collective national memory and thence the constitute a collective national identity, thereby contributing to the conscience collective, the collective sense of moral solidarity", which impacts the functioning and stability of society. By constructing national memory and narratives of nationality through narratives of history and memory, and by constructing "truth" (knowledge) through exclusion and inclusion, archives (like museums and libraries) have a role to play in "imagining" the community-nation (Anderson's "imagined" community). Or, according to the theory of performative identity (Fortier, 2000), ${ }^{7}$ everyday practices that occur in archives are institutional identity practices that contribute to the unification and homogenisation of the community through a policy of interpretation by performing and producing (performative) memory (collective identity formation).

As already mentioned, collective national identity is defined by the construction of affiliation that entails the ways in which shared history, places and experiences are created as well how they are continually (re)created and maintained (performativity) in the sense of "communion" (cf. Fortier, 2000: 1-2). Shared history as a discursive form that is constructed through collective memories constitutes an important homogenising component of collective identity that uses various fragments (points) of the past to construct memory, i.e., identity in the present. Speaking of an event that turns into a historical event, one should have in mind that this results from the relationship and correlation of the event, memory, ${ }^{8}$ representation (transformation of memory into history), and interpretation that is always tied to politics or ideology, whether it emerges from the political power that

Anne-Marie Fortier (2000) draws inspiration from Judith Butler's (2000) theory of gender performativity. According to Judith Butler, performativity is "not (...) a singular or deliberate 'act', but, rather, (...) the reiterative and citational practice by which discourse produces the effects that it names" (Butler, 1993: 2). Citation is an interpretation of the norm that is exposed as already privileged (Butler, 1993: 108). Following this direction, Fortier (2000) focuses on how non-essential identities are constructed by temporary connection points, using performativity as an act of simultaneous performance and production, and are presented as essential and natural.

8 According to White (1987: 80), memory is always emotionally coloured. 
constructs certain conditions of interpretation or a certain interpretation of a historical event is used as an aspect of ideology. ${ }^{9}$

In that context, archives play an important role in the construction and "research" of national identity because they provide evidence and establish the meaning of a shared history, which is one of the essential elements of national identity (Manoff, 2004: 16). However, the plurality of traces and the openness and incompleteness of archives (excluded fragments and an incomplete, i.e., excluded or lost context) point to the temporality of presented images of history involved in the structuring of reality, as well as their susceptibility to (re)vision (Voss and Werner, 1999: ii). Thus, the maintenance of political power depends not only on the control of archives but also on the control of remembrance, that is, memory itself (Derrida, 1995: 4). The fragmentation, openness, incompleteness or heterogeneity of materials (and their context) that are collected and stored in an archive, through which collective memory is constructed and reconstructed within the public and political spaces, cannot establish firm boundaries of "shared" memory that would form a homogeneous identity community. Interpretation and reinterpretation refer not only to the diachronic axis ("movement through history") but also to the synchronic one (heterogeneity at the same time). According to Rothberg (2009: 5), the public space is not susceptible to competitive memories that would assume clear boundaries in terms of identity or memory, but to the model of multidirectional memory. Through the pronounced complexity of the "spiral of memory discourse" (Rothberg, 2009: 11), which reveals its contingent interaction potential ${ }^{10}$ within the model of multi-directional memory, competitive memories (exclusion) are waging a hegemonic struggle for acceptance and positions of power and antagonise the social field. However, as already pointed out, there remains room to articulate shared memories (inclusion) that establish connections. The temporal dimension of multi-directional memory reflects itself as the construction of reflection (transfer of the past to the present) or a potential constructive element (transfer of the present to the future) of various contingent and open articulations or re-articulations of memory that participate in the structuring of the present and are future-oriented. The processability of identification

9 Even the perception of history (scholarly discipline) as objective, real, or socially responsible is an aspect of ideology (White, 1987: 81).

10 The contingent potential of memory is consistent with Derrida's (1990) emphasis on the indeterminacy of the future when considering archives (the meaning of archives reveals itself in the future). 
that occurs through articulation and exclusion, always including the relationship to the Other (Laclau and Mouffe, 1985), and the non-singularity and fragmentation of identity (Hall, 2006) prevent clear boundaries of memory and identity at the collective level. Multidirectional memory is, therefore, an active and complex component of the politics of memory within the public and political space that excludes the petrification of memory, and thus identity. It perceives collective memory as a complex, dynamic structure of the identification process within the interaction of collective and individual memory/identity as well as in the interaction of different collective (group) memories/identities. The fragmentation and openness of archives and their susceptibility to (re)vision is compatible with the concept of multidirectional memory within the public and political space, forming one of its constructional segments and reflecting the heterogeneity of identity within its complex dynamic structure. So, the antagonisation of the social field, as an expression of the heterogeneity, competitiveness and contradiction of various memories and their articulations, is part of the multi-directional memory within the public space. The antagonisation of the social field in the Croatian public and political space has taken place due to the shared past and memory of socialist Yugoslavia. Files of the State Security Administration of Yugoslavia (Serbian: Uprava državne bezbednosti), colloquially called the UDBA files, ${ }^{11}$ occupy a special place in this antagonisation and hegemonic struggle as part of the archival material. This even stimulated the adoption of new legislation on archival activity and archival material in $2017 .{ }^{12}$

\section{ARCHITECTURE AS AN INSTITUTIONAL APPARATUS}

One example of a clearly defined institutional apparatus as a "form of power/knowledge that constituted the institutions" (Rose, 2016: 223) is

11 See Kudra Beroš (2018) for more on the UDBA files as objects of public and political antagonistic discourses related to the (re)construction of the Croatian national identity.

12 Public and political debates over archives and archival material intensified particularly from 2015 to 2017. With Dr Zlatko Hasanbegović appointed as Minister of Culture, archival material and archives as institutions became a major motive of his political activity and were pushed to the centre of political and public discourse. The political party Bridge of Independent Lists (Croatian: Most nezavisnih lista), which entered the political arena in 2015 as a new political option, underlines amendments to the act on archives as one of the main goals of its political activity, which would include enabling access to the archival material from the SFRY period. Amendments to the Archival Material and Archives Act (Official Gazette of the Republic of Croatia, 46/17) were adopted shortly before the Government dissolution and the re-election. 
certainly architecture (Hall, 1997: 47). Brown and Davis-Brown (1998: 2021) emphasise that "institutional" architecture (a combination of form and function) is very often monumental (form) and has a property of creating value. Discussing the architecture of archives, Lilly Koltun (2002: 239) argues that the archive as a place bears various meaning: physical place, working place, public place, place of memory, place of oppression, resistance... The form of the building should correlate with its function (architectural requirement) or the work that needs to be done in it (Koltun, 2002: 241). The role of architecture in the positioning of archives within the order of political power should be considered through the lens of interdiscursivity and intertextuality, that is, through the correlations and relations of meaning produced by archival discourse. Monumentality (form) as an attributed property produces values, invokes dignity and builds a relationship to the archive as a sacred place (Brown and Davis-Brown, 1998: 20-21), reinforcing its institutional authority. On the other hand, monumentality represents the correlation between the collective (nation) and the individual (person) and their inclusion in or exclusion from the creation of memory and knowledge (truth), as well as their difference(s) in the possibility of taking the position of authority for interpretation and representation. ${ }^{13}$ The status of the archive and its involvement in the creation of memory (the political aspect) can be considered in terms of architectural importance of the archive building, or monumentality, as a reflection of the power of institutional authority and the "sacred place" of the collective, or position and meaning in social space. Architecture plays an important role in relation to the subject positions produced by a particular institution. It contributes to the creation of certain subject positions, which it also manages and supports (see Rose, 2016: 231-232). It shapes their behaviour and supports and maintains the power relations between them (e.g., the archivist - user relationship). Examining how architecture functionally meets the needs of the modern archival process and questioning architecture's impact on it can also shed light on how the archive is positioned in the order of political power, its role in constructing and structuring national identity.

The role and position of the architecture ${ }^{14}$ of the archive building can also be presented through a comparative analytical example of examining the

13 Brown and Davis-Brown (1998: 21) point out that the "boundary between institutional and freelance representatives, is but one instance of the power that is structured in and through the official knowledge discourse of the archive".

14 Architecture as function and form. 
buildings of the Croatian State Archives and the Archives of Yugoslavia. The building of the Croatian State Archives in Zagreb (which serves as the central national institution of the archival service $)^{15}$ was once the building of the National and University Library (the Archive was housed in the east wing). It was built in 1913 and constitutes the most significant example of Art Nouveau architecture in Croatia (Figures 1 and 2). The building was first intended for both the Archives and the Library, but since 1995 it has functioned only as the Archives. Although the building is architecturally and artistically impressive, it is actually inadequate when it comes to modern standards of collecting and preserving archival material. However, its impressive and representative nature (monumentality) reflects not only the place of the archive in the order of political power (as a place where common history, memory and tradition are safeguarded) within Croatian society but also the meaning of the common (national) history, memory and tradition within the construction of the Croatian national (collective) identity. The building itself is considered a monument and can be toured with an expert guide. The exhibitions, as well as the permanent exhibition of the Croatian State Archives, attach additional value to both the institutional authority itself and the objects of the archiving process. The relationship between the institutional (collective-national) and the individual is reflected in the use of the Great Reading Room (Figure 3 ) as an extremely representative (monumental) space in which various events take place. ${ }^{16}$ This adds dignity, value and institutional authority on account of its monumentality, while the individual user of the archival material is dislocated and side-lined into the "old" reading room (Figure $4)^{17}$ which is inadequate for user needs. ${ }^{18}$ Therefore, the linking of an event with the institutional importance of the Archives, as a place of "preservation of collective memory" and "shared history", gives these events an additional character of institutional identity, while also strengthening the position and role of the Archives within the institutional identity practice

15 Croatia has a network of state archives consisting of eighteen regional state archives responsible for the material produced at the local level, and the Croatian State Archives in Zagreb as the central institution.

16 These are most often various promotions and presentations that can be characterised as cultural events with the purpose of production and performance (performativity) of the Croatian national identity, but also for creating and maintaining a sense of belonging (Fortier, 2000: 133).

17 This is what the reading room is called by the staff of the Archives because it was a reading room intended for the Archives, which was located in that part of the building.

18 An extremely small and cramped space with only two computers and one reader for material on microfilm. 
and identity politics. Although the use of the material is highlighted as "a fundamental form of archival activity" today (Ćosić and Lemić, 2006: $8)$, the manner in which the Great Reading Room is used and the position of users in that process reveals the Croatian State Archives' focus on the collective, i.e., on the everyday role in various national identity representational practices. These practices are given institutional authority due to the monumentality of the space itself and the symbolic role of the archive as an institution. The architecture of the Croatian State Archives building as an institutional apparatus, as already mentioned, does not meet modern requirements and functions of archival processes, ${ }^{19}$ and its functionality within the order of political power is not as important as its monumentality (form), which adds value and dignity to "shared history", and it is used in the production and performance (performativity) of the national identity on a symbolic level and through "rituals" (events).

The Archives' position as an institutional authority in the order of political power, in addition to the monumentality of the building, is also reflected in the architectural features of the interior, which have the function of disciplining and positioning the users. Before entering the great reading room, users have to fill in an application form for the material and a statement of obligations in the adjacent room, and afterwards, they

19 Modern requirements for protecting and preserving material with guidelines issued by the International Council Archives, implemented in the Rules on the conditions of storage, equipment, protection and processing of archival material and the number and structure of archive staff $(O G, 121 / 19)$, describe and stipulate a number of spatial and architectural, protective (fire, earthquake, flood, break-in), micro-climatic (temperature, humidity, etc.) storage conditions/requirements. All of these measures have to be adapted to various old (e.g. different types of paper, inks, printing inks, photographs) and new technological forms (e.g., digital) of material production (see also Koltun, 2002: 241). Increasing the availability and usability of archival material, which is stated as the legal purpose of the Archival Material and Archives Act (OG, 61/18), and the use of archival material as an essential activity (Ćosić and Lemić, 2006: 8) puts the user at the centre of archival discourse, and the architectural form of the archive should serve this function as well. This is not the case with the Croatian State Archives because, among other things, much of the material is dislocated (at several remote locations) due to inadequate space. Thus, users sometimes have to wait several days to receive their pre-ordered material. At the same time, the Great Reading Room (which is out of service following the March 2020 earthquake) has few computers, while the old reading room has only one computer and one microfilm reader, and its working hours, as stated on the Croatian State Archives website, is from 9 am to $2 \mathrm{pm}$ for users. In addition, only twelve users can make daily visits, in two groups of six, with a break for disinfection from 11:15 am to 11:45 am, and a single user can visit only twice a week (before the COVID-19 pandemic, the working hours were until 3:45 pm and $6 \mathrm{pm}$ on Thursdays), which means that the Archives cannot be used by a large number of users and prevents continuous work (http://www.arhiv.hr/hr-hr/Istrazite-gradivo/ Citaonica-HDA). 
can access the Great Reading Room for work. The hegemonic relationship of institutional authority with the subject position of the user (which reflects the relationship of the collective/national with the individual) is best characterised in how the user approaches the counter (physical barrier of user access to experts) at which the experts-archivists ${ }^{20}$ are seated in the Great Reading Room. Upon entering the reading room, users approach the counter, report to the expert-archivist and hand in their record card. While the archivists are sitting at the counter, if users want to make a request, they have to do so with the counter reaching the top of their chests. Thus, they have to look upwards, while the expert-archivist communicating with the users looks down. This physical barrier of the counter, which both separates (places out of reach) and elevates the experts-archivists and makes them symbolically and physically superior to the users, who are placed in a position of subordination and humility (invoking awe) inherent in religious buildings and rituals, reflects the relationship that produces the value and dignity of the collective/institutional versus the individual. Users have to follow the instructions of the experts-archivists because they have the authority to remove the users from the reading room if they fail to act appropriately after being issued a warning. Users are allowed to bring stationery and a personal computer into the reading room. In addition to the extremely elevated position which is separated with a physical barrier from the user, the expert-archivist also supervises the reading room by occasionally walking between the desks. The daily communication between users and experts-archivists that takes place over the counter is what shapes their behaviours, disciplines their bodies and reflects and supports the power relations between them, but also reflects the position of institutional authority in the process of appropriating truth and knowledge. Such explicit disciplining of users also relationally positions them within the process of memory production (national identity) versus the institutional authority that appropriates the authority to perform selection (of what we will remember), interpretation and representation of memory.

20 The subject position of the expert, in this case the archivist, is produced and supported by the institutional system of science - archival science (cf. Rose, 2016: 231). 
Figure 1. Croatian State Archives

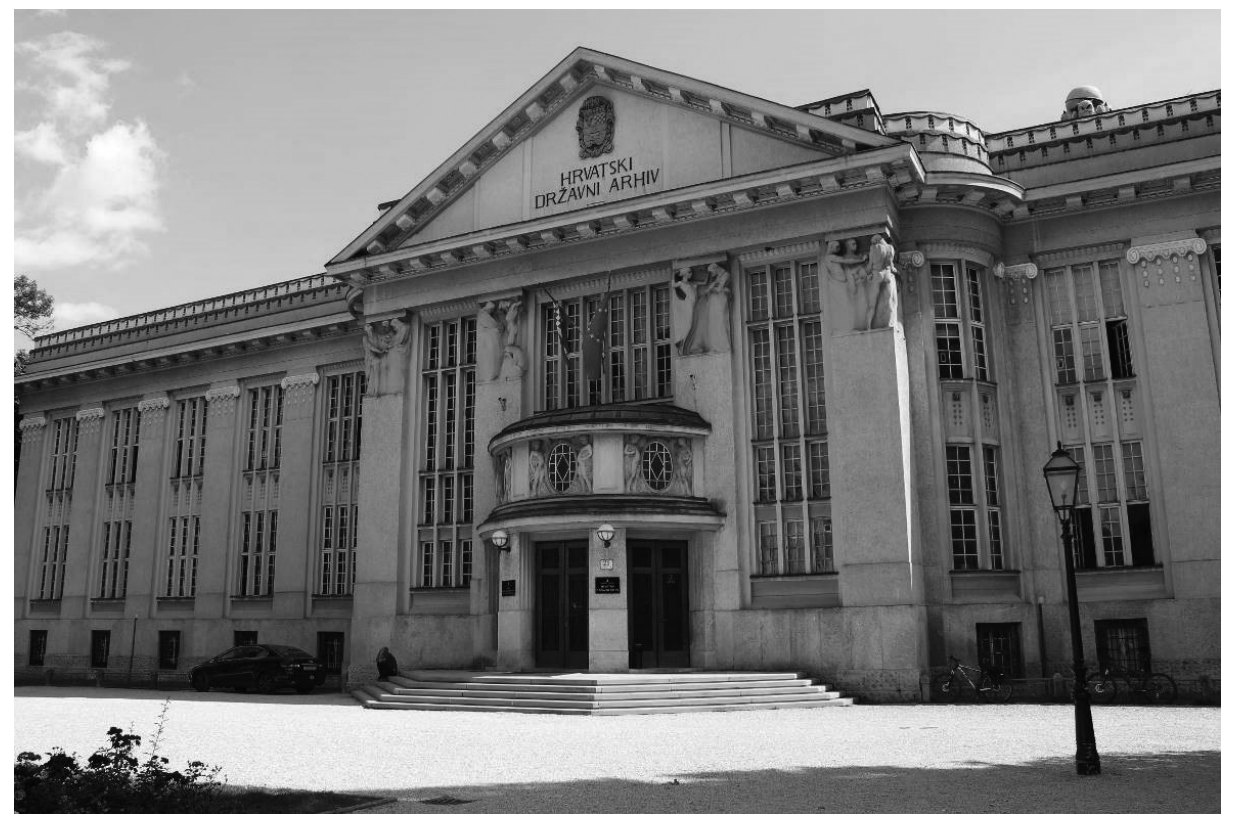

Figure 2. The position of the Croatian State Archives at Marko Marulić Square

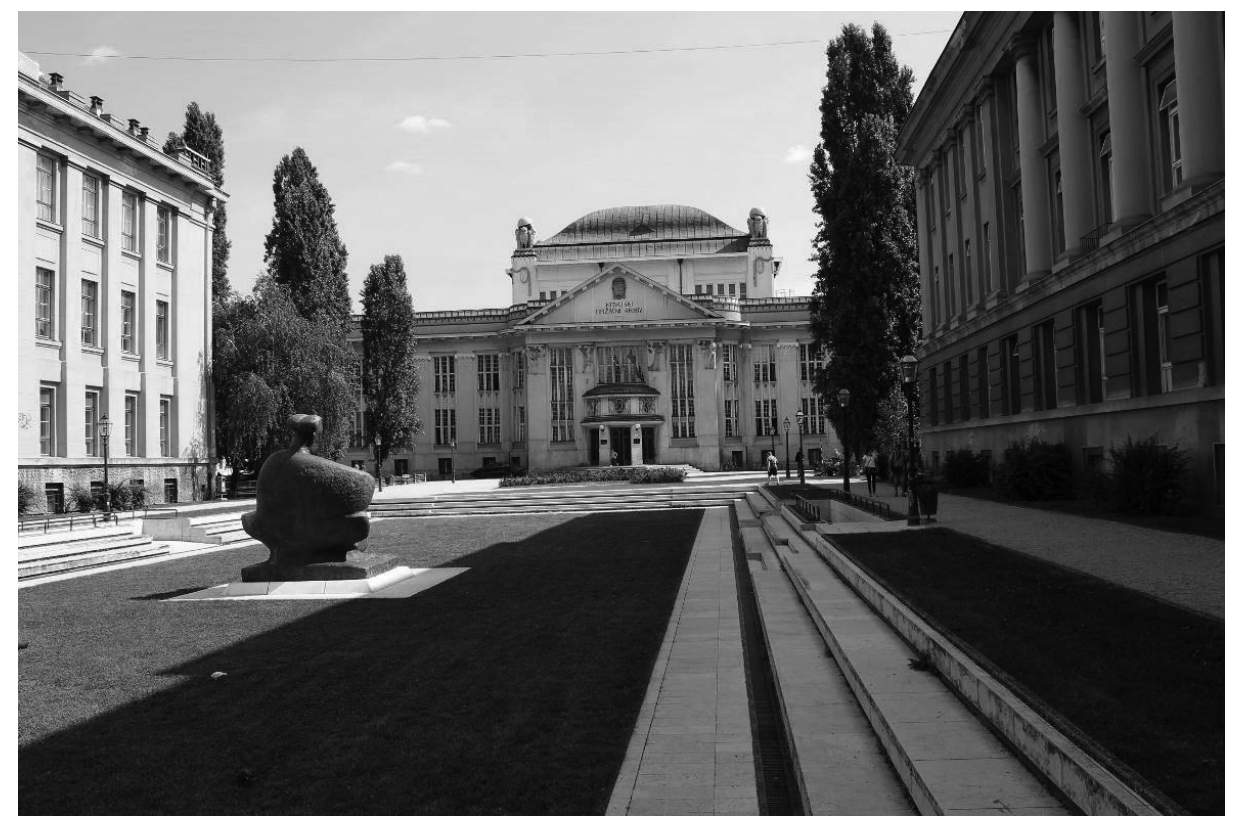


Figure 3. Gallery view of the Great Reading Room of the Croatian State Archives and the central desk where experts-archivists sit

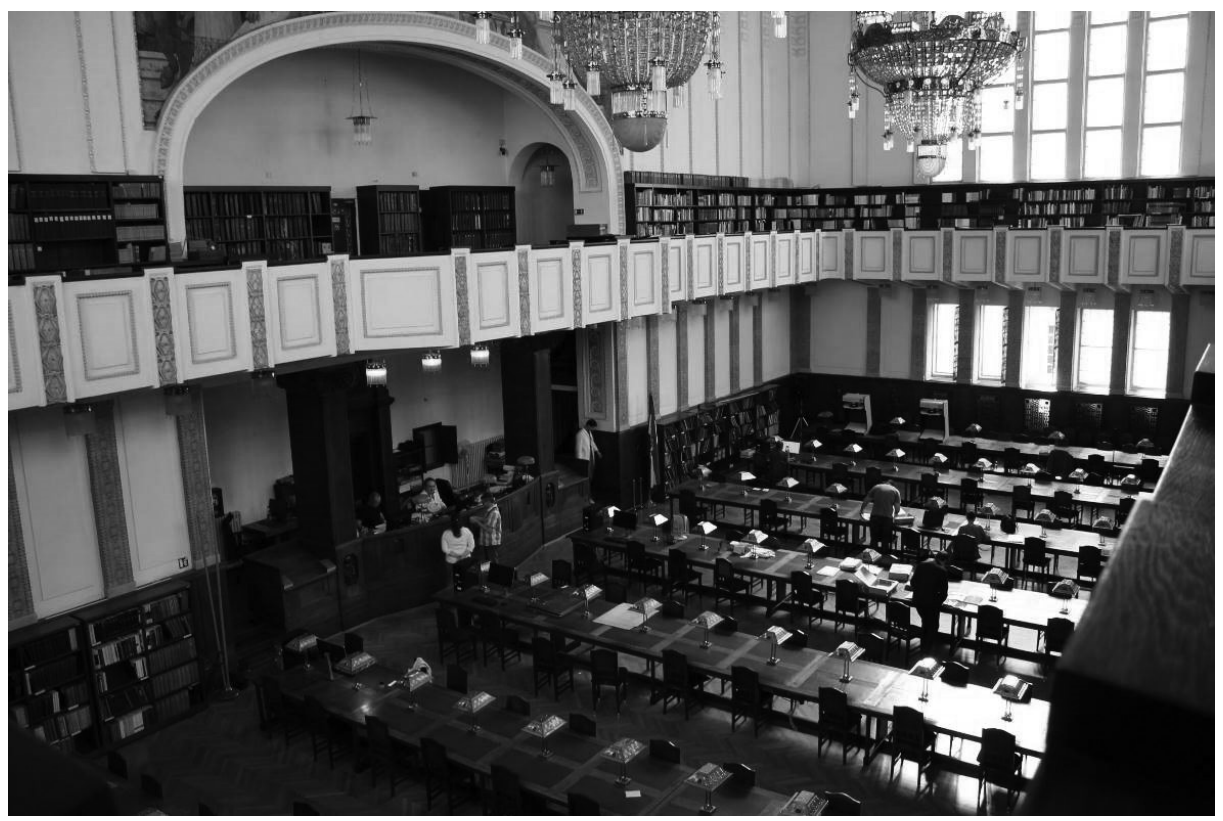

Figure 4. The "old" reading room, which is used when the Great Reading Room is "closed"

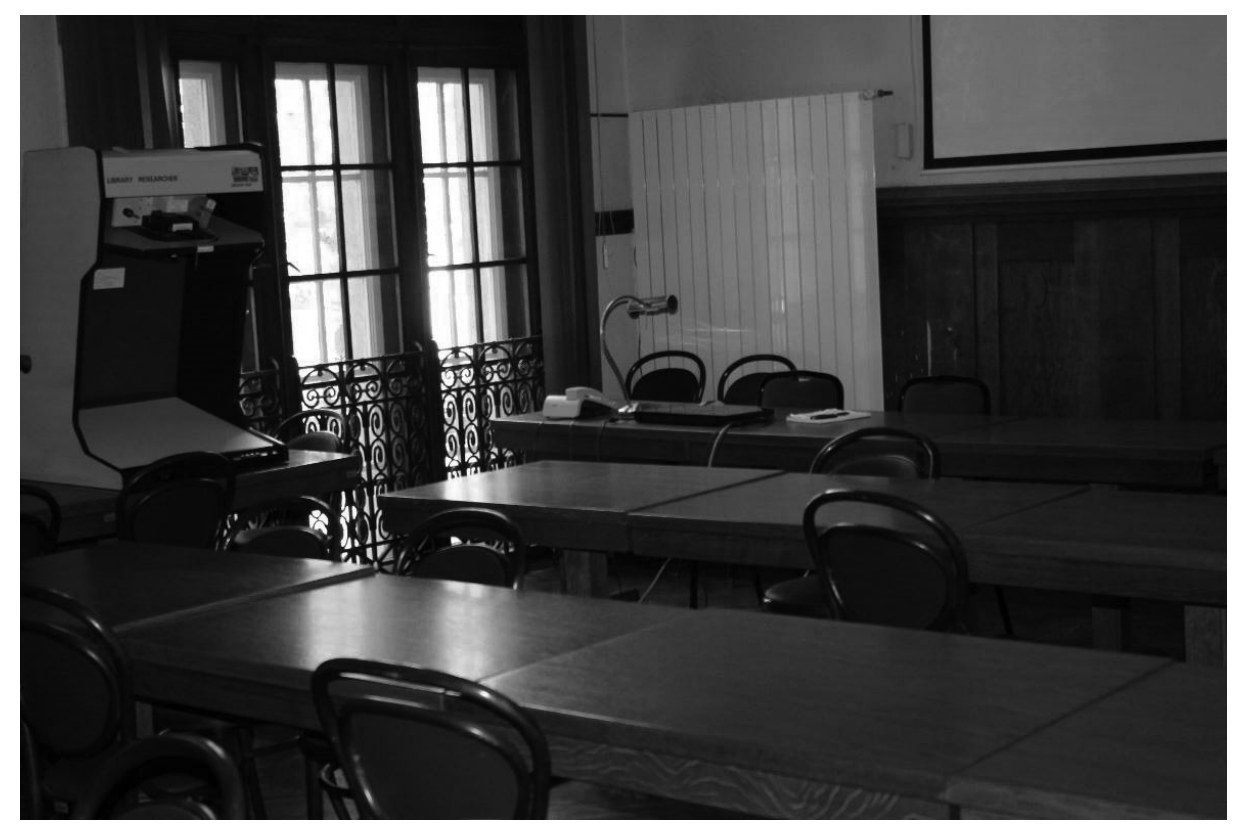


Figure 5. Archives of Yugoslavia

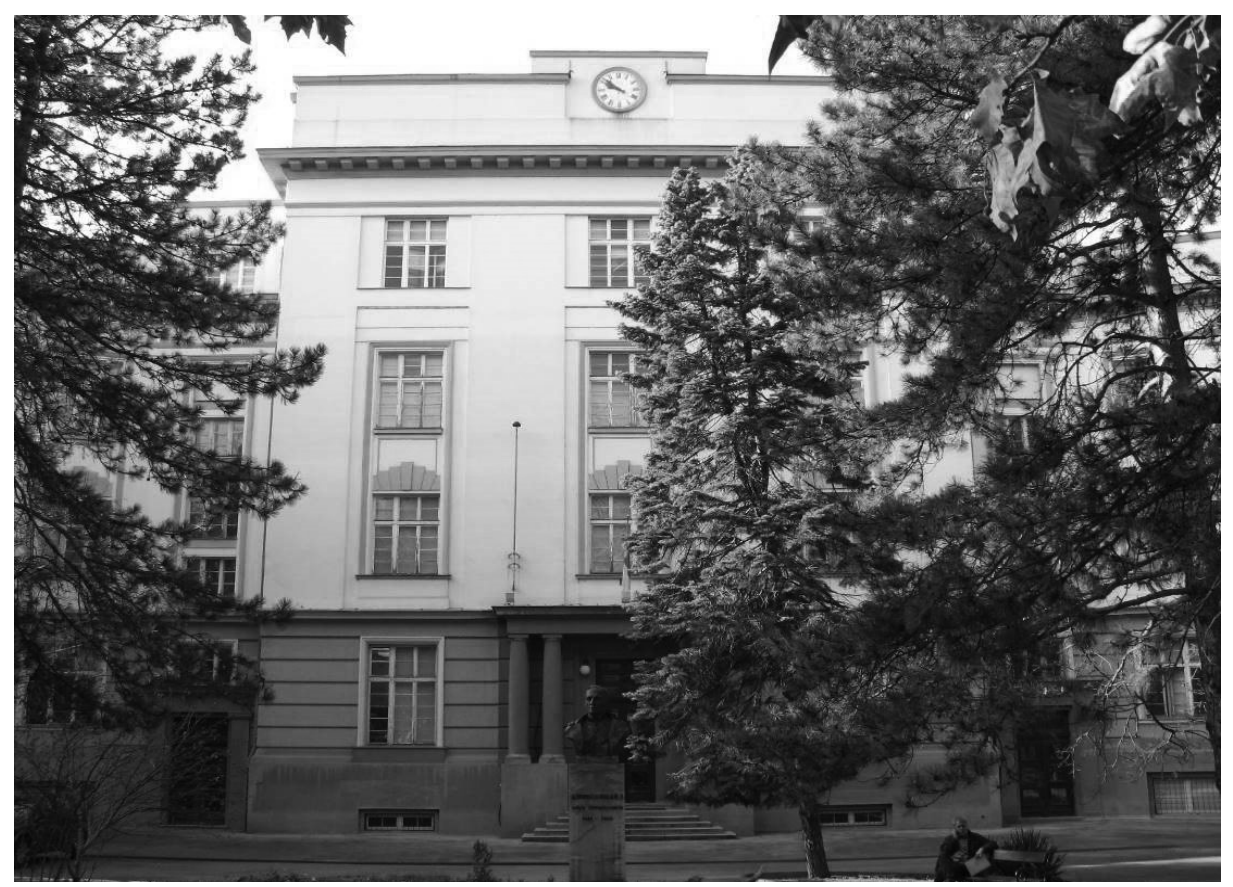

Figure 6. The reading room in the Archives of Yugoslavia

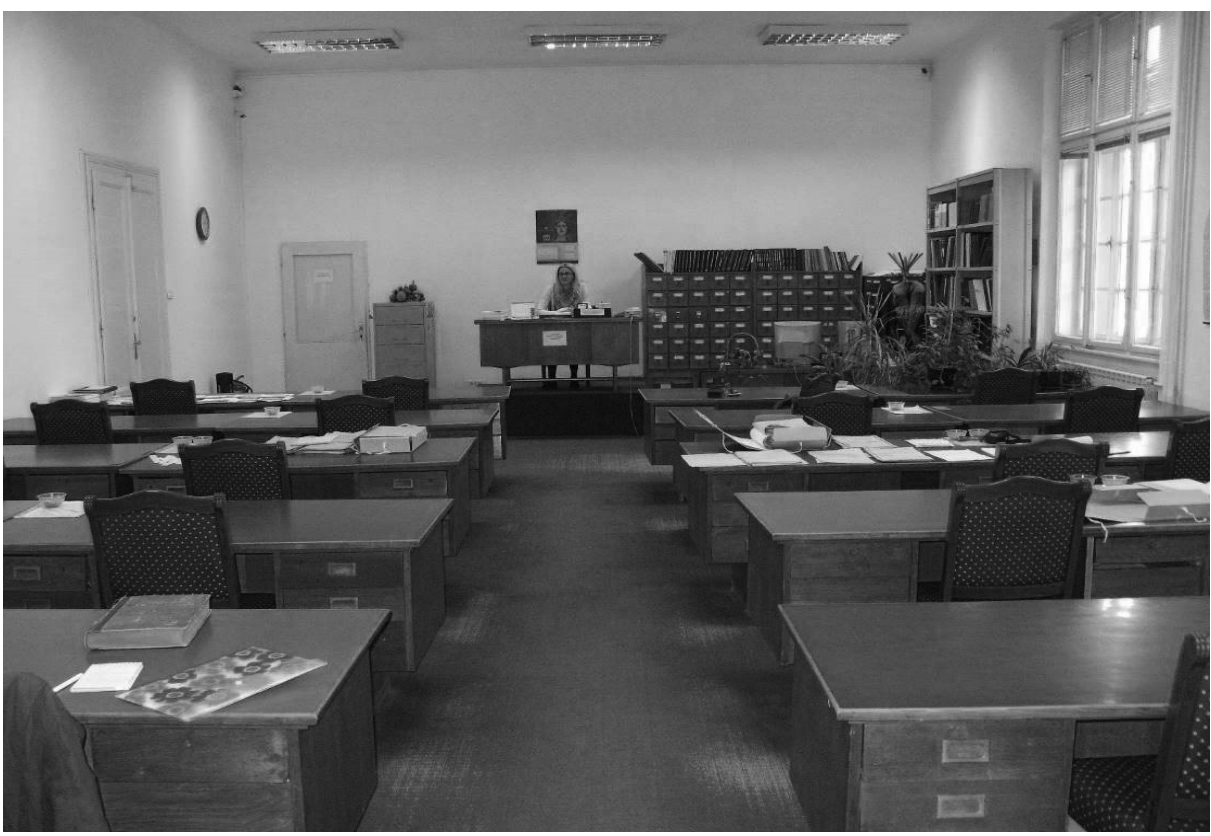


The building of the Archives of Yugoslavia was built in 1933 as a student dormitory, and it has housed the Archives since 1969 (Figures 5 and 6). The building itself is less representative in its architecture than the building of the Croatian State Archives and the building of the Archives of Serbia (Figure 7). This use of architecture serves as an illustrative example of the relations between the federal and republic archives ${ }^{21}$ in the SFRY, and their role in the construction of collective memory and history. The republic archives primarily collected material and decided what would be sent to the federal archives. Another problem was that material from the federal archives was distributed to various government bodies, i.e., the repressive system (ministries, security and intelligence services...) without any records of where the material was located and who took it. ${ }^{22}$ The relations of architectural monumentality (the form) of archives reflect the relations of institutions, their positions and meanings in the spectrum of identity practices and identity politics. The institutional creation of shared memory and the history of Yugoslavia, as well as the supranational Yugoslav identity, did not exclude the creation of individual national memories/histories/identities. However, selected objects (material selected beforehand at the republic level) were excluded from the corpus of common (Yugoslav) memory and history, or were under the control of the security-intelligence system, i.e., the institutions that then created new types of subjective positions and objects and managed the population with different technologies and mechanisms. The relationship between the user and the expert-archivist is also influenced by adjusting the function to the space and by the position of the institution. As the building of the Archives of Yugoslavia was originally intended as a school, the ways of disciplining from this institutional form were transferred to the space of the Archives. The expert-archivist sits at an elevated lectern, but there is no physical barrier between the user and the expert as in the Croatian State Archives. However, the process of ordering the desired material is done in person and by filling out a "Requirement" sheet (the material cannot be ordered by e-mail, although users can notify the Archives of their date of visit and the topic of their research) and handing it over to the

21 The relations between the federal and the republic level in Yugoslavia are often a point of contention in the construction of "shared memories" and the basis for the creation of various ideological phantasms. These relations, the roles of the republics in relation to the federal level, can be inferred from the relations between the federal and republic institutions. Igor Štiks (2016) gave an exceptional overview of these relations, as well as how their status and importance changed, i.e., how the position of the republics grew stronger in relation to the federal level through the analysis of the institute of citizenship.

22 From a conversation with a former employee of the Archives of Yugoslavia who wished to remain anonymous. 
expert-archivist (such as the relationship between students and teachers in the first half of the 20th century). The user will receive the requested material on the following day. The elevated lectern provides the expert-archivist with a good overview (supervision) of the users at the desks arranged in the room, which gives the impression of a school classroom.

This short overview of a comparative analysis of two archive buildings reveals that architecture, as an institutional apparatus, helps to infer the position and role of archives (the relationship between function and symbolic/ representational role) as an institution (institutional authority) in creating collective memories, as well as the position and role of identity politics within the political space in general.

Figure 7. Archives of Serbia

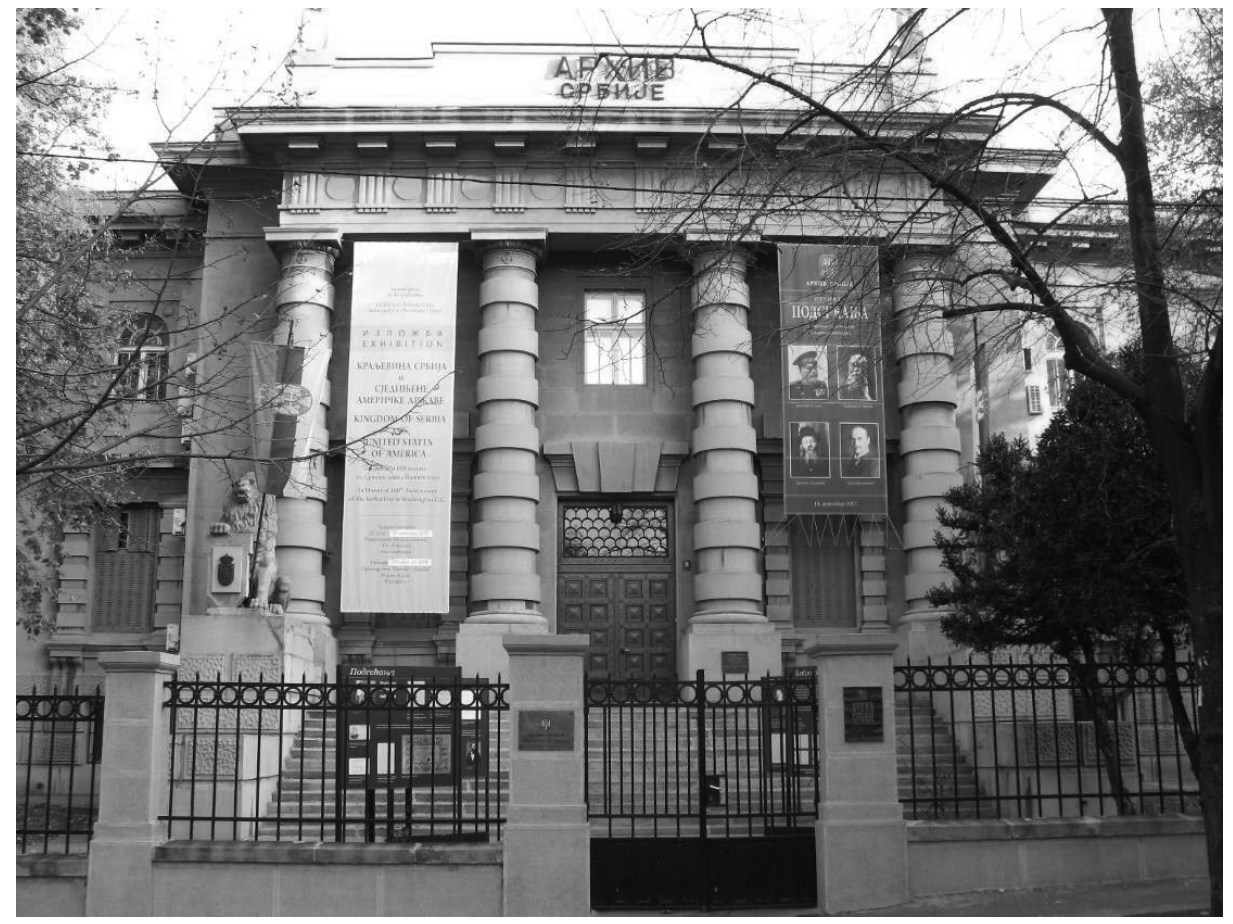

\section{EVERYDAY PRACTICE AS AN INSTITUTIONAL TECHNOLOGY - SUBJECT POSITIONS AND BUILDINGS}

By linking the possibilities of memorisation, repetition and reproduction to public space (outdoor space) (Derrida, 1995: 11) and thus enabling the 
archive as an institution, Derrida also considers archiving as a process and as the influence of technology and technique on the archive. "The technical structure of the archiving archive also determines the structure of the archivable content (...) and in its relationship to the future" (Derrida, 1995: 17; also compare Voss and Werner, 1999). On the other hand, Derrida (1995: 78) points out that gathering and collection "is never without that excessive pressure (impression, repression, suppression) of which repression (...) and suppression (...) are at least figures," while Voss and Werner (1999: i) point to the repressive and regulatory role of archives. This regulatory and repressive role affects what is stored, memorised, repeated and reproduced in the archive, that is, the process of constructing objects and creating and determining the conditions for their circulation in public space. The everyday practices that occur in archives thus reveal the political and ideological level of their activity, which requires critical consideration.

When discussing institutional technologies as applied techniques of articulating a certain form of power/knowledge (Rose, 2016: 223), these techniques of articulating and practising forms of knowledge/power take place in the archives daily through fund building or development (what is included and what is not - both the material and the context), cataloguing (what is catalogued and what is just stored), classification (formal and professional processing of material - organisation and description of knowledge shaped by dominant paradigms, either political or intellectual, i.e., both and their mutual correlations), access to material and its circulation (who and which / the impact of classification / material can be seen and in what way / differences between physical and intellectual approach) as well as protection and preservation of material and financial decisions. ${ }^{23}$ All segments of everyday practices (procedures and decisions) correlate with each other, enhancing the effects of archives in the order of political power. All those everyday archival procedures/practices reflect the regulatory and repressive role of archives (Voss and Werner, 1999: i), or power relations at the micro-level through the production of objects and subject positions. Everyday practice through technical and rational procedures (fund building, cataloguing, classification, circulation) which produce objects of dif-

23 The example of institutional technology as an applied technique of articulating a certain "form of knowledge/power" is the digitalisation of material and its public availability, where, on the one hand, the "power" of the expert mediating between material (knowledge) and users is seemingly diminished. On the other hand, that "power" is obscured because the expert still performs technical and rational procedures to decide which material will be digitalised and made publicly available. 
ferent values and meanings creates an illusion of rationality (creation of total knowledge/truth) and technicality (experts-archivists who adhere to the rules of the trade), seemingly painting a picture of apoliticism, concealing the relations of domination and power. Everyday technical and rational practices establish their authority by binding themselves to the system of science (archival science as a part of information sciences), thus reinforcing the position of appropriation of knowledge/truth, legitimising and legalising the process of exclusion (i.e., the position of power).

The basic subject positions produced by archival discourse are the employee (archivist) and the user. The subject position of the archivist (employee) - expert (the person who manages archiving processes) is reinforced by the institutional authority of the profession (appropriated knowledge/ truth). This rationalises the procedures carried out as part of the everyday practice and reinforces the archive's position of institutional authority. Produced as opposed to the subject position of the expert archivist, who uses institutional authority and the role of institutional representation that participates and "helps shape the collective national public memory" (Brown and Davis-Brown, 1998: 22), the subject position of the user (individual representation/interpretation) may be structured by various institutional authorities as "chosen" positions for interpretation and representation (e.g., historians), or precisely by the lack of institutional authority (possibility of exclusion - unavailability of "knowledge"). Such structuring of the subject position of users and differentiation with regard to the connection with various institutional authorities multiply relations of domination and create new networks of power relations with a strong ideological aspect. This process occurs, among other things, by continually collecting data on users (creating a whole new archive) and using them to manage the population. Data are collected, among other things, through the already mentioned application form for the material, which obliges the user to comply with the Rules on the use of material, the Rules on work in reading rooms and other conditions specified in the statement of obligations, which is part of the application form and includes references to the Criminal Code and the Archival Material and Archives Act, as well as reasons why certain material is requested. Each user's entry into and exit from the building is recorded electronically via an identity card. In the Archives of Yugoslavia, this practice is reduced to taking an identity document in exchange for a pass. It is also desirable to have a referral letter from an institution. Both archival institutions oblige the user to submit a copy of the book or paper that re- 
sulted from using the material. Brown and Davis-Brown (1998: 22) perceive the political and ideological level of everyday practice that occurs in the archive precisely in these technical and rational processes that create object and subject positions and their mutual relations as relations of power. At the institutional level, the exclusion of users (individual position) from various segments of access to knowledge/truth in the archive is also supported by legal regulations. Access to certain material is regulated by a series of laws and legal procedures (an example is the Croatian State Archives), ${ }^{24}$ which again, on the one hand, legitimises the power of institutional authority that produces truth/knowledge, and, on the other hand, legalises obedience (disciplining) to it through legislation (Foucault, 1980: 95). However, due to the complex network of legal provisions and procedures, the user is excluded at that level, while their knowledge about the ways of retrieving the material and its availability is inaccessible, mediated and controlled (subjective position of the expert).

The subject positions of experts-archivists, i.e., their daily practices and decisions in the Croatian State Archives, remain out of sight of users. As already mentioned, this is reinforced by both legal regulations and architecture and further strengthens the hegemonic position of institutional authority. The non-transparency of procedures, i.e., everyday practices, excludes the user, as a subject position, from archival discourse (knowledge), while the expert becomes a necessary mediator ${ }^{25}$ in the relationship between the user and the object (archival material), who directs possible interpretation with appropriated knowledge. Apart from the quality of be-

24 The non-transparency of the declassification procedure I faced in the case of Fund 1561 - SDS - RSUP - SRH (UDBA files) prompted me to consider the role of the archive as an institution. During research at the Croatian State Archives in 2014, a file that had already been declassified for a fellow historian could not be declassified for me. Instead, I had to request declassification for that file, which was never granted. It is these procedures (application for use of material, the procedure for requesting declassification for a certain type of material, procedures for obtaining approval from various instances, institutions or commissions subject to non-transparent and clear criteria) and the network of legal provisions (Archival Material and Archives Act that was applicable at the time OG, 105/97, three Acts amending the Archival Material and Archives Act OG, 64/00, 118/06, 46/17, Rules on archival material use OG, 67/99, Act on the Right to Access Information OG, 25/13, 85/15, Personal Data Protection Act OG, 103/03, 118/06, 41/08, 130/11, 160/12, Data Secrecy Act $O G, 79 / 07,86 / 12$ and Information Security Act OG, 79/07) that reinforce not only the position (of power) of archives as an institutional authority but also the position of experts-archivists as mediators between knowledge and truth and users.

25 As already mentioned, the physical positions of the expert and the user (the desk that also constitutes a physical barrier between the expert/institution and the user) outline the relations of power as well as the position of the institution and the user in the collectiveindividual relationship. 
ing "chosen", the non-transparency of procedures and the need for mediation/management (as a way of representation and interpretation) between the object and the subject position of the user adorn the object with dignity and value related to the construction of national (collective) memory, i.e., common history.

\section{ARCHIVE AS A POLITICAL AND IDEOLOGICAL INSTITUTION}

Following in the footsteps of Hage (2000: 162), one could say that the archive is a space of fantasy that structures our reality because, as he points out, it is "a mode of exhibiting oneself through idealised images of the self. More specifically, it is a fantasy of total power, a yearning for complete control where such control is impossible". Slavoj Žižek (2002: 58) points out that reality cannot be structured without elements of fantasy because it is a lens through which reality is experienced in a meaningful way. Fantasy does not deny reality; it is our way of experiencing reality, which always takes place through an ideological prism and thus constructs social relations. This "fantasy of total power" and "exhibiting oneself through idealised images of the self" (Hage, 2000: 162) is understood precisely by questioning the position of the institutional authority of archives as well as the role of architecture and subject positions established by archival discourse. One should always take note of the plurality of traces and the openness and incompleteness of the archives, which indicate the temporality and susceptibility to re(vision) (Voss and Werner, 1999: ii) of the presented image of history involved in the structuring of national identity in the present within Rothberg's multidirectional memory, but, above all, its focus on imagining an indeterminate, contingent future, as pointed out by Derrida (1995: 70). The temporality and revision of the presented image of history and collective memory, as well as the establishment of new constitutive norms of memory/history/identity, lead to "new" paradigms of exclusion and inclusion in the process of marking the difference in relation to the Other (Laclau and Mouffe, 1985). All this allows us to move away from the perception of archives as neutral places for collecting and storing objects and documents that present (record) a neutral picture of history (knowledge, truth) as a whole and to perceive the ambivalent nature of archives as places that use institutional technologies and apparatuses and fragments (objects/documents and context) to discursively construct and interpret history (knowledge/truth) while (re) constructing national identity, bringing us closer to the image of archives as political and ideological institutions that construct collective (national) 
memory, tradition and knowledge through processes of exclusion and inclusion in the hegemonic struggle, thus actively participating in the process of "imagining" the community-nation (Anderson, 1990).

\section{REFERENCES}

Anderson, B. (1990). Nacija - zamišljena zajednica. Razmatranja o porijeklu $i$ širenju nacionalizma. Zagreb: Školska knjiga.

Brown, R. H. and Davis-Brown, B. (1998). The Making of Memory. The Politics of Archives, Libraries and Museums in the Construction of National Consciousness, History of the Human Sciences, 11 (4): 17-32. https://doi.org/10.1177/095269519801100402

Butler, J. (1993). Bodies that Matters. On the Discursive Limits of "Sex". New York - London: Routledge.

Butler, J. (2000). Nevolje s rodom. Feminizam i subverzije identiteta. Zagreb: Ženska infoteka.

Ćosić, S. and Lemić, V. (2006). Rad arhiva u uvjetima suprotstavljenih utjecaja. Država društvo - korisnici, Arhivski vjesnik, 49 (1): 7-19.

Derrida, J. (1995). Archive Fever. A Freudian Impression. Chicago - London: University of Chicago Press.

Fortier, A-M. (2000). Migrant Belongings: Memory, Space, Identity. Oxford: Berg.

Foucault, M. (1980). Two Lectures, in: Gordon, C. (ed.). Power/Knowledge. Selected Interviews \& Other Writings 1972-1977. New York: Pantheon Books, 78-109.

Foucault, M. (1994). Nadzor i kazna: rađanje zatvora. Zagreb: Informator, Fakultet političkih znanosti.

Hage, G. (2000). White Nation: fantasies of white supremacy in a multicultural society. New York - London: Routledge.

Hall, S. (1997). The work of representation, in: Hall, S. (ed.). Representation: Cultural Representation and Signifying Practices. London - Thousand Oaks - New Delhi: Sage - The Open University, 13-74.

Hall, S. (2006). Kome treba identitet?, in: Duda, D. (ed.). Politika teorije. Zbornik rasprava iz kulturalnih studija. Zagreb: Disput, 357-374.

Kecskeméti, C. (1999). Integration of Separated Archives for the Preservation of National Memory, Arhivski vjesnik, 42: 209-215.

Kolbas, I. (2006). Mali pojmovnik arhivistike, bibliotekarstva i muzeologije, Arhivi, knjižnice, muzeji, http://theta.ffzg.hr/akm/AKM_ostali/pojmovnik.html\#arhivistika (18 July 2017).

Koltun, L. (2002). The Architecture of Archives. Whose Form, What Functions?, Archival Science, 2: 239 -261. https://doi.org/10.1007/bf02435624

Kudra Beroš, V. (2018). Dosjei UDBE kao problematični objekt (re)konstrukcije hrvatskog nacionalnog identiteta, Etnološka tribina, 48 (41): 159-173. https://doi.org/10.15378/ 1848-9540.2018.41.05

Laclau, E. and Mouffe, C. (1985). Hegemony and Socialist Strategy: Towards a Radical Democratic Politics. London: Verso.

Manoff, M. (2004). Theories of the Archive from Across the Disciplines, Portal: Libraries and the Academy, 4 (1): 9-25. https://doi.org/10.1353/pla.2004.0015 
Nora, P. (2006). Između pamćenja i historije. Problematika mjesta, in: Brkljačić, M. and Prlenda, S. (eds). Kultura pamćenja i historija. Zagreb: Golden marketing - Tehnička knjiga.

Rose, G. (2016). Visual methodologies: An introduction to the interpretation of visual Materials. London: Sage Publication.

Rothberg, M. (2009). Multidirectional Memory: Remembering the Holocaust in the Age of Decolonization. Stanford: Stanford University Press.

Štiks, I. (2016). Državljanin, građanin, stranac, neprijatelj: jedna povijest Jugoslavije i postjugoslavenskih država. Zaprešić: Fraktura.

Voss, P.J. and Werner, M. L. (1999). Toward a Poetics of the Archive:Introduction, Studies in the Literary Imagination, 32 (1): i-viii.

White, H. (1987). The Content of Form: Narrative Discourse and Historical Representation. Baltimore - London: Johns Hopkins University Press.

Žižek, S. (2002). Sublimni objekt ideologije. Zagreb: Arkzin.

\title{
Arhiv kao mjesto čuvanja zajedničkih sjećanja, povijesti i identiteta
}

\section{Viktorija Kudra Beroš}

\begin{abstract}
SAŽETAK
Pozivajući se na čuvanje i zaštitu autentičnog i vjerodostojnog traga prošlosti (dokumenata) pa time i nacionalnog identiteta, arhivi se prikazuju kao mjesta »izabranosti« za interpretiranje i reprezentiranje zajedničkog sjećanja i prošlosti. Pozivanje na autentičnost i vjerodostojnost čini arhive naizgled politički i ideološki neutralnim institucijama. No, taj trag koji nam daje na uvid »istinu i znanje « vlastite (i individualne i kolektivne) prošlosti »koji nas čini onime što jesmo« zahtjeva propitivanje. S obzirom da proces arhiviranja počiva na procesima uključivanja i isključivanja u svim segmentima svakodnevne prakse te interpretacije građe/gradiva arhiv se ukazuje kao politička i ideološka institucija koja zauzima svoje mjesto u poretku političke moći. U ovom radu razmatra se uloga arhiva kao mjesta čuvanja "zajedničke prošlosti i povijesti« kao važne sastavnice nacionalnog identiteta kroz prizmu institucionalnih aparata odnosno formi znanja/moći (primjer arhitekture) i tehnologija odnosno načina artikuliranja i prakticiranja znanja/moći (primjer svakodnevne prakse). Rad ukazuje na ulogu i poziciju arhiva u (re)interpretaciji i (re)viziji zajedničkih sjećanja, kolektivne povijesti kao i nacionalnog identiteta na primjerima Hrvatskog državnog arhiva i Arhiva Jugoslavije, a u kontekstu promjene simboličkog i političkog poretka (SFRJ / Hrvatska). Konstruirajući nacionalno sjećanje i narative nacionalnosti kroz narative povijesti i sjećanja, isključivanjem i uključivanjem konstruirajući »istinu « (znanje), arhivi (kao i muzeji i knjižnice) imaju svoju ulogu u »zamišljanu « zajednice - nacije ili u skladu s performativnom teorijom identiteta (Foritier, 2000) svakodnevna praksa koja se u arhivima odvija institucijska je identitetska praksa koja izvodeći i proizvodeći (performativnost) sjećanje (kolektivna identitetska formacija) sudjeluje u unificiranju i homogeniziranju zajednice putem politike interpretacije.
\end{abstract}

KLJUČNE RIJEČI: arhiv, sjećanje, nacionalni identitet, Hrvatski državni arhiv, Arhiv Jugoslavije 